REPORTS OF MORPHOLOGY
$\begin{gathered}\text { Official Journal of the Scientific Society of Anatomists, } \\ \text { Histologists, Embryologists and Topographic Anatomists } \\ \text { of Ukraine } \\ \text { journal homepage: https://morphology-journal.com }\end{gathered}$

\title{
The role of the CagA gene in the occurrence of the inflammatory response of the gastric mucosa in patients with chronic Helicobacter pylori-associated gastritis
}

Vernigorodskiy S.V., Sukhan D.S.

National Pirogov Memorial Medical University, Vinnytsya, Ukraine

\section{ARTICLE INFO}

Received: 03 July, 2018

Accepted: 06 August, 2018

UDC: $616.33-002.2: 579.835: 575.113$

\section{CORRESPONDING AUTHOR}

e-mail: vernset@ukr.net Vernygorodskyi S.V.
Currently, Helicobacter pylori infection ( $H$. pylori) is recognized as one of the most important risk factors for gastrocarcinogenesis. It is known that this infection does not directly cause neoplastic changes in the gastric mucosa, and this is due to a number of consecutive events due to the long persistence of the pathogen in the human body. The initial stage of this cascade, of course, is the inflammatory response, due to the body's ability to adapt to extraneous infection, which is the inevitable result of the interaction of $\mathrm{H}$. pylori with cells of the gastric epithelium. This direct damaging effect is enhanced by the production of vacuolating cytotoxin and the release of products of the cytotoxin-associated CagA gene, which, at a pathomorphological level, is manifested by inflammatory infiltration of the gastric mucosa (GM) to some extent. On the relationship between the degree of contamination and the activity of the inflammation of the GM in people infected with the CagA strain, today there are different, often conflicting opinions, which is why in this work we set the goal of establishing the relationship between the nature of the inflammatory response and the presence of the CagA gene in H. pylori-infected patients. The purpose of the study is to determinate the relationship between the nature of the inflammatory response and the genetic features of the $H$. pylori strain (CagA genotype). We examined 365 patients, among whom 40 people were included in the control group (18 women and 22 men, whose average age was $45,33 \pm 15,46$ and $42,82 \pm 12,31$, respectively) without any gastroenterological pathology in the anamnesis , patients with chronic non-atrophic gastritis (188 people) and chronic atrophic gastritis (137 people). A close relationship was established between the presence of the CagA gene, activity and the degree of contamination for chronic nonatrophic gastritis (CNG): for a low degree of contamination, Fisher's exact test was = $0.002, p<0.05$, for a moderate degree $-0.012, p<0.05$, for a high degree - 0,012, $p<0.05$. Accordingly, in chronic atrophic gastritis (CAG): for a low degree of contamination Fisher's exact test $=0.011, p<0.05$, for a moderate degree $-0.003, p<0.05$, for a high degree $-0.001, p<0.05$. There is also a close relationship between the degree of contamination and the activity of chronic gastritis (CG): in patients with a high degree of contamination, CG activity was determined, as a rule, for stage 2-3. In our study, the inflammatory response depended on the presence or absence of the $\mathrm{H}$. pylori strain in the patient, which contains the CagA genotype, which, in our opinion, plays a key role in triggering a cascade of inflammatory changes in the GM and progression of chronic gastritis.

Keywords: Helicobacter pylori, CagA, chronic gastritis, morphological changes.

\section{Introduction}

The correlation of chronic inflammation with gastric cancer was established in 1863 by the famous German pathologist R. Virchow [27]. The discovery of Helicobacter pylori has revolutionized previous perceptions of the nature of gastroduodenal pathology and noted this unique infectious agent as a specific cause of CG, peptic ulcers and stomach cancer. The International Kyoto Consensus first proposed an etiological classification of gastritis and recommended that $\mathrm{H}$. pylori-induced $C G$ should be considered as an infectious disease requiring treatment 
not so much to alleviate symptoms as to prevent complications such as peptic ulcer and gastric cancer [7, $32,36]$. The property of $\mathrm{H}$. pylori to induce the development of inflammatory, dysplastic, metastatic and neoplastic changes depends on factors related to the microorganism itself, the organism of the host and the environment. The main pathogenicity genes include: CagA (cytotoxinassociated gene $A$ ); VacA (vacuolating cytotoxin); IceA (induced by contact with epithelium); BabA (blood group antigen-binding adhesin). $\mathrm{H}$. pylori genes in the so-called "pathogenicity island" cag (cagA pathogenicity island, cag $\mathrm{PAI}$ ) due to the activation of NF-kB (nucleic factor kappa-B) are involved in the development of an inflammatory response by initiating a cascade of signal transduction, leading to interleukin IL-8 production. As a result, proinflammatory cytokines and cellular (Th-1-mediated) immune response lead to further progression of inflammatory response $[4,17$, $18,28,22]$.

The high frequency of peptic ulcer disease and the onset of MALT-lymph in Europe is due to the presence of CagA. CagA strains of $\mathrm{H}$. pylori are also associated with pronounced epithelial cell proliferation and GM metaplasia [6]. In western countries, there have also been reports that individuals infected with CagA-positive strains are more likely to develop stomach ulcer and cancers than those infected with $\mathrm{H}$. pylori CagA-negative strains. However, there was no such dependence on the inhabitants of East Asia [40]. Most authors argue that there is a close correlation $[9,10,11,14,24,26]$, others believe that CagA-positive / negative strains of H.pylori are not related to the development of severe gastroduodenal pathology and do not find any significant differences in the activity of inflammation and colonization in different types of $H$. pylori infection $[4,13,19]$.

That is why the purpose of our study was to establish the relationship between the nature of the inflammatory response and the genetic features of the $\mathrm{H}$. pylori strain (presence of CagA genotype).

\section{Materials and methods}

The study group consisted of 325 people with CG diagnosis: 111 women (mean age $49.85 \pm 13.41$ ) and 214 men (mean age $48.81 \pm 13.61$ ). The control group included 40 persons ( 18 female and 22 male, mean age $45.33 \pm 15.46$ and $42.82 \pm 12.31$, respectively) without gastrointestinal pathology in history (Table 1). Among patients with CG, the following groups were isolated: chronic non-atrophic gastritis (188 persons) and chronic atrophic gastritis (137 people). In the survey, the ethical principles of the Helsinki Declaration of the World Medical Association (World Medical Association Declaration Helsinki, 1964) were followed. All patients were informed and signed informed consent, confirming their voluntary participation in the study.

In the course of fibroesophagogastroduodenoscopy, multiple biopsies were performed - 2 biopsies from the body and antrum of the stomach and 1 from the angle of the stomach. Pathologist examination of biopsies for the
Table 1. Distribution of patients according to nosology depending on age.

\begin{tabular}{|c|c|c|c|c|}
\hline Nosology & $\begin{array}{c}\text { up to } 25 \\
\text { (m/f) }\end{array}$ & $\begin{array}{c}26-44 \\
(\mathrm{~m} / \mathrm{f})\end{array}$ & $\begin{array}{c}45-59 \\
(\mathrm{~m} / \mathrm{f})\end{array}$ & $\begin{array}{l}60 \text { and } \\
>(\mathrm{m} / \mathrm{f})\end{array}$ \\
\hline Normal GM & $4(2 / 2)$ & $19(11 / 8)$ & $11(7 / 4)$ & $6(2 / 4)$ \\
\hline $\begin{array}{l}\text { CNG without } \\
\text { dysplasia }\end{array}$ & $10(7 / 3)$ & $27(18 / 9)$ & $14(9 / 5)$ & $5(3 / 2)$ \\
\hline $\begin{array}{l}\text { CNG with } \\
\text { dysplasia: } \\
\text { Mild } \\
\text { Severe }\end{array}$ & $\begin{array}{l}4(3 / 1) \\
3(2 / 1) \\
1(1 / 0)\end{array}$ & $\begin{array}{c}42(29 / 13) \\
29(20 / 9) \\
13(9 / 4)\end{array}$ & $\begin{array}{c}56(36 / 20) \\
33(21 / 12) \\
23(15 / 8)\end{array}$ & $\begin{array}{c}30(20 / 10) \\
17(11 / 6) \\
13(9 / 4)\end{array}$ \\
\hline $\begin{array}{l}\text { CAG without } \\
\text { dysplasia }\end{array}$ & - & $8(5 / 3)$ & $10(6 / 4)$ & $22(14 / 8)$ \\
\hline $\begin{array}{l}\text { CAG with } \\
\text { dysplasia: } \\
\text { Mild } \\
\text { Severe }\end{array}$ & $\begin{array}{l}2(1 / 1) \\
2(1 / 1) \\
-\end{array}$ & $\begin{array}{c}19(14 / 5) \\
15(12 / 3) \\
4(2 / 2)\end{array}$ & $\begin{array}{c}43(28 / 15) \\
31(19 / 12) \\
12(9 / 3)\end{array}$ & $\begin{array}{c}33(21 / 12) \\
19(13 / 6) \\
14(8 / 6)\end{array}$ \\
\hline Total & $20(13 / 7)$ & $115(77 / 38)$ & $134(86 / 48)$ & $96(60 / 36)$ \\
\hline
\end{tabular}

diagnosis was performed in accordance with the requirements of the morphological section of the modified Sydney-Houston system [5, 23]. Determination of the persistence of $\mathrm{H}$. pylori in $\mathrm{GM}$ was performed using urease test [20], cytologically by Pappenheimer [21] and histologically - colored by Giemsa and toluidine blue by B. Slater [31]. The genotyping of helicobacter infection was performed using a polymerase chain reaction. For further comparative analysis with the results of genotyping $\mathrm{H}$. pylori we used own data obtained from the inspection of 40 practically healthy persons, among which 17 were infected with $\mathrm{H}$. pylori. To determine the degree of dysplasia, the criteria proposed by WHO experts [3], and developed on the basis of the Vienna classification of neoplasia of the gastrointestinal epithelium [30] were used. In the presence of $\mathrm{H}$. pylori infection, all cases of observations were divided into two groups: $\mathrm{H}$. pyloripositive and $\mathrm{H}$. pylori-negative.

Statistical processing was performed using Microsoft Office Excel 2007 and "Statistica 5.0". Calculated the average arithmetic value $M$, its error $m$. The reliability of the difference between the average values was estimated by the Students criterion, the difference was considered to be valid at $p<0.05$. In order to check the statistical hypotheses of absolute and relative frequencies in independent samples, the chi square $\left(X^{2}\right)$ criterion was used, with the frequency of the investigated event less than 5 observations for the analysis of frequency differences in the two independent groups used Fisher's exact criterion, the confidence intervals given in the work, were constructed for confidence probability $p=95 \%$. In all statistical analysis procedures, the achieved level of significance $(p)$ was calculated, with the critical level of significance taken equal to 0.05 .

\section{Results}

In the control group, both in $\mathrm{H}$. pylori-negative patients $(-)$ and in $\mathrm{H}$. pylori-positive (+), GM maintained its histoarchitectonics, regardless of the presence of CagA + . 
The cytological smear is usually clean. In the two $\mathrm{H}$. pylori $(+)$ individuals, focal degenerative changes in the pyloric glands were established. At the same time, according to anamnesis, they also had signs of dyspepsia. In histological analysis, GM in practically healthy individuals consisted of a subepithelial layer which width was determined by the depth of the pits and glands, the ratio of which was approximately 1:3. Gastric pits were located close to each other. Surface epithelium cells, as a rule, had a highly prism form and a clear polar differentiation.

At morphological analysis of GM of patients with CNG CagA negative (CagA-) helicobacter infection without dysplasia it was established that in the group of inactive CNG surface and pit epithelium cells, exocrinocytes of fundal and pyloric glands in histological sections and smearsimprints retained their structure, were located predominantly in layers and groups, looked monomorphic, the nuclei were pushed to the periphery of cells, round-oval, their contour was equal. Chromatin homogeneous coarse-grained, intensely colored. The cytoplasm is weakly basophilic. Exocrinocytes of the glandular epithelium of the antral department of GM were located in groups and palisade-like structures, had larger sizes in comparison with superficial ones. The nuclei in them were located eccentrically, more oval, some of them containing single small correct form of the nucleolus.

In 15 (55.56\%) patients with acute $\mathrm{H}$. pylori (CagA-) CNG without dysplasia and 8 with mild dysplasia (29.63\%) epithelial cells had a similar look, but dystrophic changes were accompanied by the appearance of dysregeneration in the form of hyperchromatosis, a violation of the location of nuclei and a nuclear-cytoplasmic ratio, as well as a basophilia of the cytoplasm of individual epithelial cells, more often present a few neutrophils and lymphocytes that were mainly infiltrated in GM lamina propria with its slight perivascular edema (Fig. 1), indicating weak activity and corresponded to the first stage according to L.Y. Aruina et al. (1998) [1].

The division of gastritis in the stage of activity was determined by the degree of neutrophilic infiltration of GM lamina propria. At the first stage of activity there was a slight leukocyte infiltration of GM lamina propria, while in the second occurred infiltration of the surface and pit epithelium with enhanced leukodiapedesis and the inflow of inflammatory cells to the lumen of the stomach. In the third stage, along with the pronounced infiltration of GM lamina propria and the epithelial layer, there were so-called "intra-pit abscesses", similar to "crypt-abscesses" in inflammatory diseases of the colon [1, 2, 16]. Their formation was through massive leukodiapedesis through the thickness of the epithelium to the lumen of the pits, and also accompanied by a powerful destruction of the epithelial layer.

At moderate and high levels of contamination, which corresponded to the 2nd and 3rd stages of CNG activity, both in CagA- and CagA $+\mathrm{H}$. pylori-infected patients, the above features increased significantly. At the same time,

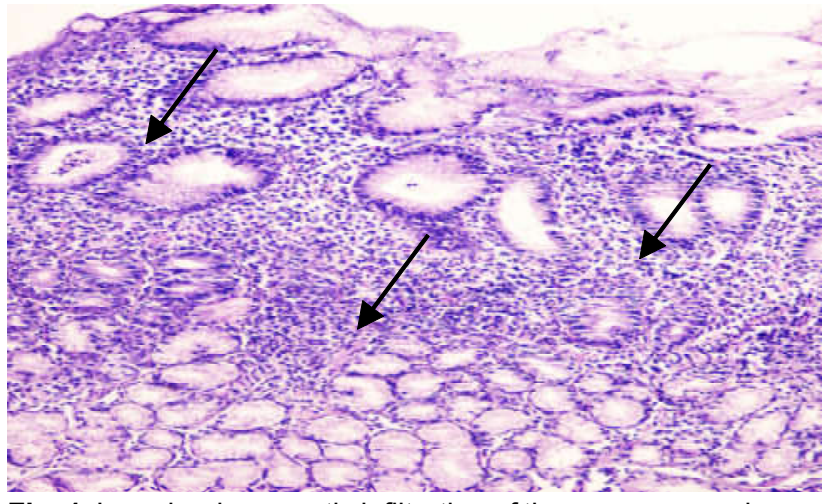

Fig. 1. Lymphoplasmacytic infiltration of the mucous membrane lamina propria with admixture of segmental neutrophils and dystrophic changes of surface and pit epithelium. Chronic nonatrophic active (stage 1) gastritis without dysplasia. CagA-. The arrows show the areas of lymphoplasmacytic infiltration of the mucous membrane lamina propria. Hematoxylin-eosin. x100.

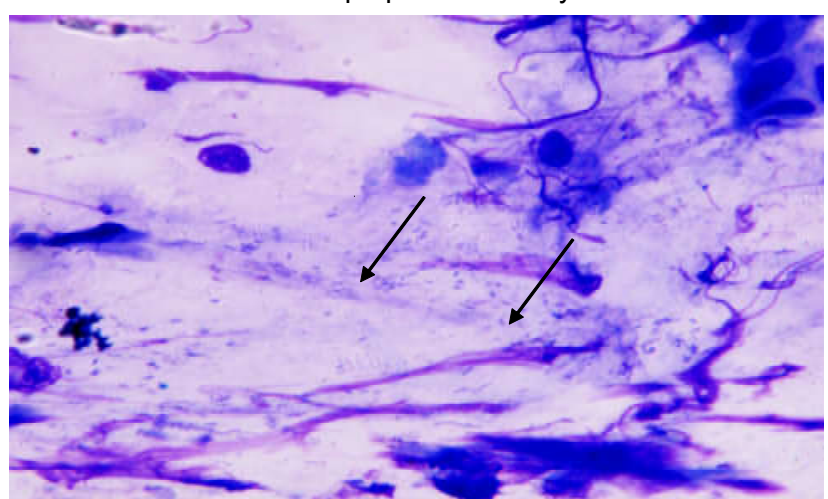

Fig. 2. Moderate degree of contamination of GM, more than $20 \mathrm{H}$. pylori bacteria in the field of vision (x1000) in a patient with CNG $(\mathrm{CagA}+)$. The arrows show the areas of the $\mathrm{H}$. pylori conglomeration. Bacterioscopy by Pappenheimer. $x 1000$.

among and intraepithelial localization of microorganisms in comparison with the low degree of contamination and the first stage of activity prevailed in the cytoplasm of the superficial and pit epithelium with a high degree of contamination and 3 stages of activity in $76 \%$ of $\mathrm{H}$. pylori CagA+ patients.

At the same time, in patients with CNG with CagAnegative (CagA-) among and intraepithelial localization of microorganisms was observed in $10 \%$ of patients with high degree of contamination and 3 stages of activity compared with low and 1 stage. However, in patients with CAG CagA+, among and intraepithelial localization of microorganisms was observed only in $35 \%$ of cases with a high degree of contamination and 3 stages of activity, and CagA- in 5\%. With a low degree of contamination and 1 stage of activity in both groups of $\mathrm{CG} \mathrm{H}$. pylori was determined predominantly in the adjacent to the surface epithelium mucus.

For $\mathrm{CNG}(\mathrm{CagA}+)$ with moderate and high contamination in smears-imprints, an increase in the number of layer and groups of epithelial cells, as well as in the glandular structures, was likely to be attributed to the weakening of 
The role of the CagA gene in the occurrence of the inflammatory response of the gastric mucosa in patients with...

intercellular connections (associated with both the activity of inflammation - leukopedesis and with the persistence of helicobacter infection) and easier getting into the imprint (Fig. 2).

Part of the epithelial structures was characterized by signs of dystrophy, manifested by the flattening of cellular forms, vacuolation of the cytoplasm, weakening of the contours of the membranes, loosening of the chromatin structure. The cells of the glandular epithelium were also represented in a greater number, among them observed moderate polymorphism. Along with the epithelial cells producing mucus, the presence of groups and glandular structures of proliferating cells with basophilic cytoplasm and absence of signs of secretion in the part of cells, a small increase in the nuclear-cytoplasmic ratio, starting with the generative zone of the gland, was confirmed. Such a picture created the impression of some polymorphism of epithelial cells. The intensity of mononuclear infiltration (degree of inflammation) in patients with CNG and CAG showed mild, moderate and severe degree of inflammation. At a significant degree of inflammation, along with the increase in the density of infiltration, formed clusters, which pushed the glands with the spread of it deep into the mucous membrane, up to the basal part. The accumulation of lymphocytes in mucous membrane lamina propria was diverse in terms of volume, cell density, structure and depth of occurrence. At a minimal and moderate extent, the formation of small groups of lymphocytes in the basal parts of the mucous membrane was observed. An increase in the volume of mononuclear inflammatory infiltrates in mucous membrane lamina propria occurred due to the formation of follicles. They were observed as bundles of oval or round shape, which consisted of tightly adjacent small lymphocytes. In a number of follicles there were light centers - reproduction, indicating a sufficient immune response of the body. The level of colonization of the mucosal by CagA $(+)$ strains of $\mathrm{H}$. pylori directly correlated with activity and degree of inflammation, both patients with CNG and CAG.

Dysplastic changes in the gastric epithelium in patients with CNG were detected in $43 \mathrm{H}$. pylori-, among which light dysplasia was observed in $28(65.12 \%)$, and severe in 15 $(34.88 \%)$. While GM dysplasia was registered at $89 \mathrm{H}$. pylori + patients with CNG, among which in CagA- 12 patients with dysplasia - 8 cases were with mild dysplasia $(66.67 \%)$, while the severity was twice as low - 4 (33.33\%). In the morphological analysis of dysplastic changes in GM of patients with CNG CagA $+\mathrm{H}$. pylori strains, it was found that among 77 patients with dysplasia, it was mild in $46(59.74 \%)$ and severe in 31 (40.26\%) (Table 2).

The activity of CAG, as well as CNG, irrespective of the presence of dysplasia, correlated positively with the bacterial colonization of $\mathrm{GM}$ : cases with severe $(+++)$ infection respectively was mainly second or third stage of CAG activity (Table 3).

CAG with the first stage of activity in cytological preparations and on histological sections, painted with
Table 2. Characteristics of the examined patients depending on the presence of the gene CagA H. pylori.

\begin{tabular}{|l|c|c|}
\hline \multicolumn{1}{|c|}{ Nosology } & CagA (-)N, $\mathbf{m} / \mathbf{f}$ & CagA (+)N, $\mathbf{m} / \mathbf{f}$ \\
\hline Normal GM & $12(6 / 6)$ & $5(3 / 2)$ \\
\hline CNG without dysplasia & $15(8 / 7)$ & $11(7 / 4)^{\star}$ \\
\hline CNG with dysplasia & 12 & $77^{*}$ \\
Mild & $8(5 / 3)$ & $46(30 / 16)^{\star}$ \\
Severe & $4(2 / 2)$ & $31(21 / 10)^{\star}$ \\
\hline CAG without dysplasia & $12(7 / 5)$ & $9(6 / 3)$ \\
\hline CAG with dysplasia & 16 & $48^{*}$ \\
Mild & $12(8 / 4)$ & $31(22 / 9)^{\star}$ \\
Severe & $4(2 / 2)$ & $17(11 / 6)^{\star}$ \\
\hline Total: & $\mathbf{6 7 ( 3 8 / 2 9 )}$ & $\mathbf{1 5 0 ( 1 0 0 / 5 0 )}$ \\
\hline
\end{tabular}

Notes: ${ }^{*} p<0,05$ - in comparison with the norm.

Table 3. Characteristics of the examined patients depending on the stage of contamination, the stage of activity and the presence of CagA.

\begin{tabular}{|l|c|c|c|c|c|c|}
\hline \multirow{2}{*}{ Nosology } & \multicolumn{3}{|c|}{ CagA(-) } & \multicolumn{3}{c|}{ CagA(+) } \\
\cline { 2 - 8 } & + & ++ & +++ & + & ++ & +++ \\
\hline CNG inactive & 11 & 5 & 4 & 7 & 5 & 0 \\
\hline CNG active & $\mathbf{3}$ & $\mathbf{2}$ & $\mathbf{2}$ & $\mathbf{2 0}$ & $\mathbf{2 3}$ & $\mathbf{3 3}$ \\
\hline 1 stage & 2 & 1 & 1 & 9 & 6 & 3 \\
\hline 2 stage & 1 & 1 & 1 & 8 & 10 & 13 \\
\hline 3 stage & 0 & 0 & 0 & 3 & 7 & 17 \\
\hline CAG inactive & 7 & 6 & 5 & 3 & 0 & 1 \\
\hline CAG active & $\mathbf{3}$ & $\mathbf{3}$ & $\mathbf{4}$ & $\mathbf{1 5}$ & $\mathbf{1 0}$ & $\mathbf{2 8}$ \\
\hline 1 stage & 1 & 2 & 1 & 8 & 2 & 3 \\
\hline 2 stage & 2 & 1 & 3 & 6 & 7 & 8 \\
\hline 3 stage & 0 & 0 & 0 & 1 & 1 & 17 \\
\hline Total & $\mathbf{2 4}$ & $\mathbf{1 6}$ & $\mathbf{1 5}$ & $\mathbf{4 5}$ & $\mathbf{3 8}$ & $\mathbf{6 2}$ \\
\hline
\end{tabular}

toluidine blue, heliobacteria were well visualized in the form of curved sticks. At a weak degree colonization - single (up to 20 in the field of view with an increase of 1000 times) bacterial bodies were found in the pit mucus, more often outside the epithelium in some fields of view.

For moderate colonization of GM by heliobacteria, the location of microbes, in the mucus, and in the lumen of the pits near the epithelium, was typically, where we observed from 20 to 50 bacteria in the field of view, which coincides with the data of Aruin, 1998 [1]. In cases of severe contamination along with epithelial cells and glandular structures, more than 50 microbial bodies were found as in the pits in the form of bacterial accumulation in many fields of vision and in adjacent to the surface epithelium of the mucus, gastric pits, and sometimes in the lumen of the glands.

Histological analysis of GM of patients with CAG for 2 stages of activity was characterized by diffuse leukocyte infiltration both in the surface and in the pit epithelium, and segmental leukocytes sometimes destroy the neck of the glands (Fig. 3 ). In the 3 stages of CAG activity, neutrophils were detected in both the surface and pit epithelium and in 


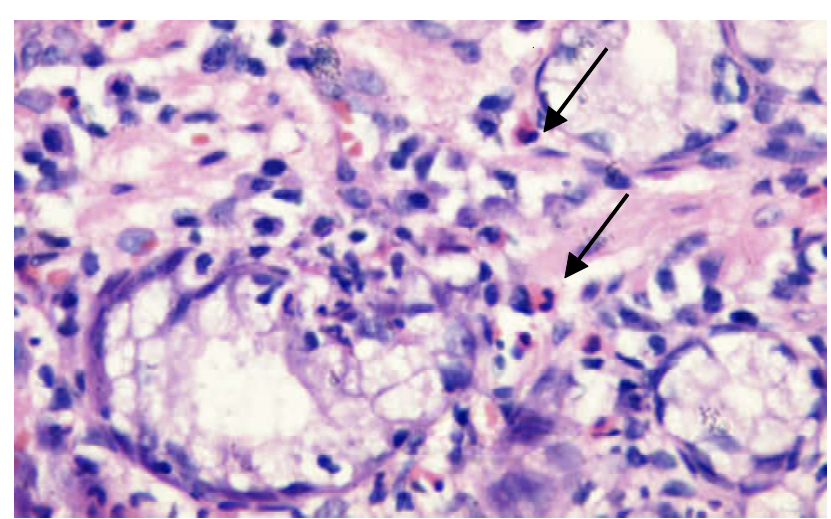

Fig. 3. Chronic atrophic active (stage 2) gastritis CagA+. Leukocyte infiltration of the mucous membrane lamina propria of the antral part of the stomach. The arrows show segmented neutrophils in mucous membrane lamina propria. Hematoxylin-eosin. x1000.

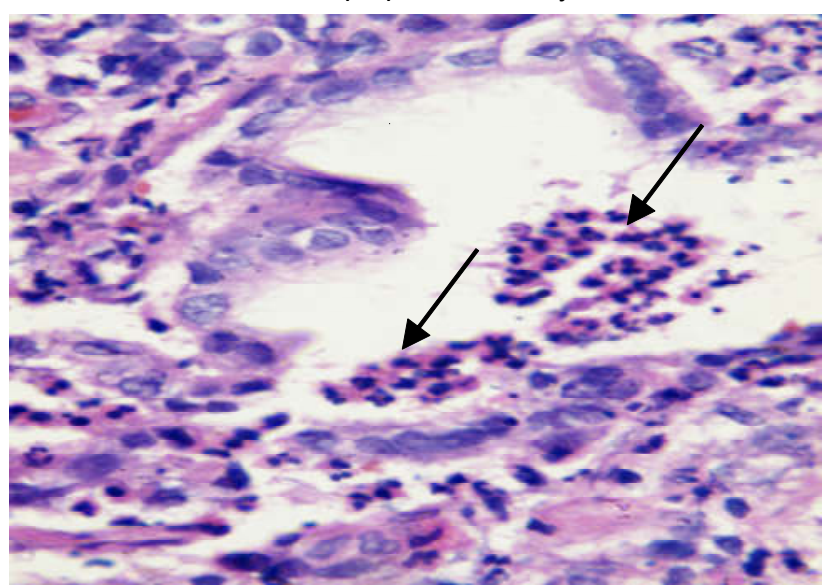

Fig. 4. Chronic atrophic active (stage 3 ) gastritis. CagA+. Leukodiapedesis with the formation of "intra-pit abscess". The arrows show the accumulation of segmental leukocytes inside the stomach pits. Hematoxylin-eosin. x1000.

the lumen of the glands with the formation of intrapit and glandular abscesses (Fig. 4).

In some sites, micro-erosions were observed as a small surface defect of the epithelial layer. Also, areas of epithelium of regenerative type with basophilic nuclei with high activity of inflammation were observed. Most often erosions were combined with the 2 nd and 3rd stage of inflammation activity, as well as with the strong $\mathrm{H}$. pylori contamination.

The parameters for CAG patients were follow: 31 (64\%) of 48 patients had mild dysplasia and $17(36 \%)$ with severe (see Table 2). At a severe degree of dysplasia, the severity of cellular atypia increased in patients both with CAG and CNG.

In the comparative pathomorphological analysis of GM in $\mathrm{H}$. pylori+ and $\mathrm{H}$. pylori-patients with $\mathrm{CAG}$ with dysplastic changes, it should be noted that 1 stage of atrophy was positively correlated with the degree of infectivity $\left(X^{2}=0.046\right.$, $p<0.05)$, while for $2,3,4$ stages of atrophy $\left(x^{2}=0,2773, p>\right.$ 0,$05 ; X^{2}=0,382, p>0,05 ; X^{2}=0,555 ; p>0,05$ respectively), such dependence has not been established. In our opinion, this is due to the key role of helicobacter infection, which triggers a cascade of pathological changes in GM. With further progression of atrophic changes in the gastric epithelium, GM loses the ability to synthesize mucin, which leads to the reduction of adhesive properties and the inability of $\mathrm{H}$. pylori to bind to glycoproteins of gastric mucus.

Thus, conducted studies indicate that the presence of CagA positive genotype of helicobacter infection in patients with CG complicates the prognosis of the underlying disease, causing a cascade of pathological changes in GM.

Histologic and molecular genetic comparisons conducted in the studied groups of patients showed that the lowest degree of chronic gastritis activity was observed in GM of body and anthrax in uninfected patients and infected with $\mathrm{H}$. pylori CagA (-) strains, and the minimum bacterial insemination rates - in the body of the stomach in patients infected with the strains of CagA (-) H. pylori.

Study of the activity of inflammation (neutrophil infiltration) of GM in chronic gastritis confirmed the association with helicobacter infection (see Table 3). The statistical analysis revealed a high reliability between inflammation activity and the presence of helicobacter infection $(\mathrm{CagA}+)$, and with CNG: for a low degree of contamination, the exact Fisher criterion $=0.002, p<0.05$, for moderate degree $-0.012, p$ $<0.05$, for high degree $-0.012, p<0.05$. Accordingly, for CAG: for a low degree of contamination, the exact Fisher criterion $=0,011, p<0,05$, for a moderate degree $-0,003, p<0,05$, for a high degree $-0,001, p<0,05$. The highest values of gastric activity rates were noted for the antrum department in patients with CNG infected with CagA $(+) \mathrm{H}$. pylori strains and in patients with the third stage of CAG activity infected with $\mathrm{H}$. pylori (+) strains. The highest degree of bacterial insemination was recorded by us in the antral department of the stomach in patients with CNG of the third stage of activity infected with the strains of CagA $(+) \mathrm{H}$. pylori.

\section{Discussion}

The main role in the mechanism of neutrophilic chemotaxis plays an epithelium, in which the expression of cytokines, leukotriene B4 and complement activation products occurs with adhesion [15, 28, 42]. The protein that activates neutrophils stimulates the adhesion of leukocytes to endothelial cells, which in turn changes microcirculation, leads to degranulation of tissue basophil granulocytes (mast cells), leukocytes and platelet aggregation and transudation. The leading role in chemotaxis belongs to interleukin-8, the main source of which is the gastric epithelium. Adhesion causes in epitheliocytes reorganization of actin cytoskeleton and increases the expression of the gene encoding interleukin-8, and then triggers the inflammatory cascade with the secretion of various cytokines [33, 39, 41]. In addition to direct bacterial stimulation of the epithelial production of interleukin-8, its expression is enhanced by the factor of tumor necrosis and interleukin-1, which are produced by macrophages and leukocytes, which migrate to the sites of colonization $[25,29]$. A vicious circle with a long active process is created. The data we receive are in agreement with the data of N. Tegtmeyer et al. [34], which also revealed the 
association of CagA + strains infection of the $\mathrm{H}$. pylori with CG activity, due to the ability to directly stimulate the secretion of the epithelium of interleukin-8, with almost exclusively strains of type $1(\mathrm{Cag} A+, \operatorname{Vac} A+)[34]$ and do not coincide with the data given by Y. Yamaoka in 1999 [40], which did not establish a significant difference in the relationship between the activity of inflammation with the colonization in different types of $\mathrm{H}$. pylori infection.

It should be noted that most studies have shown that with the presence of $\mathrm{H}$. pylori in the cytotoxin-associated gene, the relative risk of these diseases increases by $2-3$ times, and some authors point to an increased risk of developing gastric cancer in $\mathrm{CagA}+\mathrm{H}$. pylori infection in 28.4 times [35, 37, 38]. The cellular composition of inflammatory infiltrates of GM is undergoing significant changes in the $\mathrm{H}$. pylori infection, which are more non-specific, and in terms of prediction regarding the risk of pre-cancerous development, should be interpreted in conjunction with other factors and indicators involved in the pathogenesis of dysplastic changes in SOS. In our study, the degree of colonization, as a rule, corresponded to the stage of activity, as in cases of CNG, and in patients with CAG, which coincides with the data $[8,12]$.

By initiating damage, $\mathrm{H}$. pylori causes chronic inflammation in GM. This inflammation is mediated by multitude pro- and anti-inflammatory cytokines. Genetic polymorphism directly influences changes in the intensity of the cytokine response, which causes definitive clinical effects in humans [35]. Clinical and morphological manifestations of helicobacter infection depend on genetic factors of pathogenicity of the microorganism and genetic predisposition of the infected organism.

\section{References}

[1]Aruin, L. I., Kapuller, L. L., \& Isakov, V. A. (1998). Morphological diagnosis of diseases of the stomach and intestines. M.: "Triad-X".

[2] Aruin, L. I., Kononov, A. V., \& Mozgovoy, S. I. (2009). International classification of chronic gastritis: what should be accepted and what is in doubt. Archive of pathology, 4, 11-18.

[3] Bosman, F. T., Carneiro, F., Hruban, R. H., \& Theise, N. D. (2010). World Health Organization Classification of Tumours. Pathology and Genetics of Tumours of the Digestive System. IARC Press. Lyon, 417.

[4] Chukov, S. Z., \& Pasechnikov, V. D. (2001). Do H. pylori virulence factors determine the nature of the gastroduodenal pathology? Russian Journal of Gastroenterology, Hepatology, Coloproctology, 11(2), 75-81.

[5] Dixon, M. F., Michael, D., \& Path, F. R. (1996). Classification and Grading of Gastritis: The Updated Sydney System. The American Journal of Surgical Pathology, 20(10), 1161-1181.

[6] Evstigneev, I. V. (2011). Infection caused by Helicobacter pylori: state of the problem and prospects. Klinichna Imunologiya. Allergology Infectology, 6-7, 14-19.

[7] Gaddy, J. A., Radin, J. N., Loh, J. T., Zhang, F., Washington, M. K., Peek, R. M., \& Cover, T. L. (2013). High Dietary Salt Intake Exacerbates Helicobacter pylori-Induced Gastric Carcinogenesis. Infection and Immunity, 81(6), 2258-2267. doi:10.1128/iai.01271-12.
The data obtained by us is sufficiently promising for further research of the relationship between helicobacter infection in the epithelium of GM and precancerous changes in the stomach with the features of the clinical course of the disease and the composition of cellular infiltration. Although the role of another $\mathrm{H}$. pylori infectious agent in the gastric cancer etiology has been substantiated, however, not all pathogenetic links in the participation of $\mathrm{H}$. pylori in gastrocarcinogenesis have been fully elucidated. Perhaps they are also due to the effect on the composition of inflammatory cellular infiltration of GM and the production of some cytokines by $\mathrm{H}$. pylori-induced epithelial cells, macrophages and other cells.

Further study of genetic factors of virulence with the use of polymerase chain reaction is promising, since it will allow not only the prediction of the course of chronic gastritis, depending on the strain detected, but also to optimize and develop new differentiated approaches to eradication therapy.

\section{Conclusions}

The degree of activity of both chronic non-atrophic and atrophic gastritis depended on the presence of CagA. At the same time, the closest correlation is recorded between the degree of infectivity and the stage of activity. Thus, in chronic non-atrophic gastritis: for a low degree of contamination, the exact Fisher criterion was 0.002 , with $p<0.05$, for a moderate degree $-0.012(p<0.05)$, and for high -0.012 ( $p<0.05)$. Accordingly, for chronic atrophic gastritis: for a low degree of contamination, Fisher's exact criterion was 0.011 , at $p<0.05$, for a moderate degree $0.003(p<0.05)$, for a high degree $-0.001(p<0.05)$.

[8] Ghasemi Basir, H. R., Ghobakhlou, M., Akbari, P., Dehghan, A., \& Seif Rabiei, M. A. (2017). Correlation between the Intensity of Helicobacter pylori Colonization and Severity of Gastritis. Gastroenterology Research and Practice, 1-5. doi:10.1155/ 2017/8320496.

[9] Hatakeyama, M. (2014). Helicobacter pylori CagA and Gastric Cancer:A Paradigm for Hit-and-Run Carcinogenesis. Cell Host \& Microbe, 15(3), 306-316. doi:10.1016/j.chom.2014.02.008.

[10] Isaeva, G. S., \&Valiyeva, R. I. (2018). Biological properties and virulence of Helicobacter pylori. KMAH, 1 (20), 14-23.

[11] lunusova, A. I., Litvinova, I. S., Karpeno, P. A., \& Tohidpour, A. (2017). The Cytotoxin-Associated Gene A (CagA) of Helicobacter pylori: the Paradigm of an Oncogenic Virulence Factor. Journal of Siberian Federal University. Biology, 1-12. doi:10.17516/1997-1389-0015.

[12] Ivanova, N. L., Sokolova, I. L., Sadovnikova, V. V., \& Smirnova, E. M. (2003). The activity of the inflammatory process in the gastric mucosa, depending on the degree of contamination of helicobacter pylori in children. Medikum, 3-4, 24-31.

[13] Jenks, P. J., Megraud, F., \& Labigne, A. (1998). Clinical outcome after infection with Helicobacter pylori does not appear to be reliably predicted by the presence of any of the genes of the cag pathogenicity island. Gut, 43, 752-758.

[14] Kamogawa-Schifter, Y., Yamaoka, Y., Uchida, T., Beer, A., Tribl, B., Schöniger-Hekele, M., \& Dolak, W. (2018). Prevalence 
of Helicobacter pylori and its CagA subtypes in gastric cancer and duodenal ulcer at an Austrian tertiary referral center over 25 years. PLOS ONE, 13(5), e0197695. doi:10.1371/ journal.pone.0197695

[15] Kido, M., Tanaka, J., Aoki, N., Iwamoto, S., Nishiura, H., Chiba, T., \& Watanabe, N. (2009). Helicobacter pylori Promotes the Production of Thymic Stromal Lymphopoietin by Gastric Epithelial Cells and Induces Dendritic Cell-Mediated Inflammatory Th2 Responses. Infection and Immunity, 78(1), 108-114. doi:10.1128/iai.00762-09

[16] Kononov, A. V. (2006). Inflammation as the basis of Helicobacter pylori - associated diseases. Archive of pathology, 5, 3-10.

[17] Kononov, A. V. (2009). Genetic regulation and phenotype of inflammation in Helicobacter pylori infection. Archive of pathology, 5, 57-63.

[18] Lee, J. Y., Kim, N., Choi, Y. J., Nam, R. H., Choi, Y. J., Kwon, Y. H., \& Lee, D. H. (2014). Histologic Findings and Inflammatory Reactions After Long-term Colonization of Helicobacter felis in C57BL/6 Mice. Journal of Cancer Prevention, 19(3), 224230. doi:10.15430/jcp.2014.19.3.224

[19] Maeda, S., Yoshida, H., Ikenoue, T., Ogura, K., Kanai, F., Kato, N. ... Omata, M. (1999). Structure of the cag pathogenicity island in Japanese Helicobacter pylori isolates. Gut, 44, 336-341.

[20] Medvetsky, Ye. B., \& Vilcanyuk, I. O. (2001). Method of staining Helicobacter pylori in cytological preparations. Reports of morphology, 7(1), 154-155.

[21] Morozov, I. A. (2000). Cytological diagnosis of Helicobacter pylori infection in the stomach. Russian Journal of Gastroenterology, Hepatology, Coloproctology, 2, 7-10.

[22] Mozgovoy, S. I., Novikov, D. G., \& Kononov, A. V. (2010). Assessment of the integral indicator of mucosal atrophy in chronic gastritis in the prognosis of gastric cancer. Omsk Scientific Herald, 1, 81-83.

[23] Mozgovoy, S. I., Shimanskaya, A. G., \& Osintseva, I. L. (2010). Russian revision of the international classification of chronic gastritis: evaluation of a new diagnostic approach using Capastatistics methods. Omsk Scientific Herald, 1, 84-88.

[24] Nizhevich, A. A., Kuchina, E. S., \& Akhmadeeva, E. N. (2012). The value of anti-CagA serological immune response in children with gastric ulcer and duodenal ulcer associated with helicobacter pylori. Basic research, 4(1), 212-215; URL: http:/ /www.fundamental-research.ru/ru/article/view?id=29746.

[25] Nomura, S., Yamaguchi, H., Ogawa, M., Wang, T. C., Lee, J. R., \& Goldenring, J. R. (2005). Alterations in gastric mucosal lineages induced by acute oxyntic atrophy in wild-type and gastrin-deficient mice. American Journal of PhysiologyGastrointestinal and Liver Physiology, 288(2), G362-G375. doi:10.1152/ajpgi.00160.2004.

[26] Park, J., Forman, D., Waskito, L., Yamaoka, Y., \& Crabtree, J. (2018). Epidemiology of Helicobacter pylori and CagA-Positive Infections and Global Variations in Gastric Cancer. Toxins,10(4), 163. doi:10.3390/toxins 10040163.

[27] Perwez Hussain, S., \& Harris, C. C. (2007). Inflammation and cancer: An ancient link with novel potentials. International
Journal of Cancer, 121(11), 2373-2380. doi:10.1002/ijc.23173

[28] Polyzos, S. A. (2017). Helicobacter pylori infection and esophageal adenocarcinoma: a review and a personal view. Annals of Gastroenterology. doi:10.20524/aog.2017.0213

[29] Potrokhova, E. A., Pomorgailo, E. G., \& Kononov, A. V. (2012). Variants of the course of $\mathrm{H}$. pylori-associated gastritis in adolescents after eradication of the pathogen. Russian Bulletin of Perinatology and Pediatrics, 2, 46-51.

[30] Schlemper, R., Riddell, R., \& Kato, Y. (2000). Vienna classification of gastrointestinal epithelial neoplasia. Gut,47(2), 251-255.

[31] Slater, B. (1990). Superiorstain for Helicobacter pylori usingtoluidine. Journal of Clinical Pathology, 43(11), 961.

[32] Sugano, K., Tack, J., Kuipers, E. J., Graham, D. Y., El-Omar, E. M., Miura, S., \& Malfertheiner, P. (2015). Kyoto global consensus report on Helicobacter pylorigastritis. Gut, 64(9), 1353-1367. doi:10.1136/gutjnl-2015-309252

[33] Suzuki, N., Murata-Kamiya, N., Yanagiya, K., Suda, W., Hattori, M., Kanda, H., \& Hatakeyama, M. (2015). Mutual reinforcement of inflammation and carcinogenesis by the Helicobacter pylori CagA oncoprotein. Scientific Reports, 5(1). doi:10.1038/ srep10024.

[34] Tegtmeyer, N., Wessler, S., \& Backert, S. (2011). Role of the cag-pathogenicity island encoded type IV secretion system in Helicobacter pylori pathogenesis. FEBS Journal, 278(8), 11901202. doi:10.1111/j.1742-4658.2011.08035.x

[35] Tkach, S. M. (2009). H. pylori infection as a major cause of gastric carcinogenesis. Health of Ukraine, 1, 32-33.

[36] Tkach, S. M. (2016). Modern approaches to the classification, diagnosis and management of patients with chronic gastritis in the light of the international Kyoto consensus. Gastroenterologiya, 1, 110-116.

[37] Tsukamoto, T., Nakagawa, M., Kiriyama, Y., Toyoda, T., \& Cao, X. (2017). Prevention of Gastric Cancer: Eradication of Helicobacter Pylori and Beyond. International Journal of Molecular Sciences, 18(8), 1699. doi:10.3390/ijms18081699

[38] Vieth, M., Dirshmid, K., Oehler, U., Helpap, B., von Luckner, A. G., \& Stolte, M. (2001). Acute measles gastric infection. The American Journal of Surgical Pathology, 25(2), 259-62.

[39] Walduck, A., Schmitt, A., Lucas, B., Aebischer, T., \& Meyer, T. F. (2004). Transcription profiling analysis of the mechanisms of vaccine-induced protection against $\mathrm{H}$. pylori. The FASEB Journal, 18(15), 1955-1957. doi:10.1096/fj.04-2321fje.

[40] Yamaoka, Y., Kodama, T., Gutierrez, O., Kim, J. G., Kashima, K., \& Graham, D. Y.(1999). Relationship between Helicobacter pylori iceA, cagA and vacA status and clinical outcome: studies in four different countries. Journal of Clinical Microbiology, 37(7), 2274-2279.

[41] Zhang, X.-Y., Zhang, P.-Y., \& Aboul-Soud, M. A. M. (2016). From inflammation to gastric cancer: Role of Helicobacter pylori. Oncology Letters, 13(2), 543-548. doi:10.3892/ol.2016.5506.

[42] Zhang, Y., Pan, K., Zhang, L., Ma, J., Zhou, T., \& Li, J. (2015). Helicobacter pylori, cyclooxygenase-2 and evolution of gastric lesions: results from an intervention trial in China. Carcinogenesis, bgv147. doi:10.1093/carcin/bgv147.

\section{РОЛЬ CagА ГЕНАУ ВИНИКНЕННІ ЗАПАЛЬНОЇ ВІДПОВІДІ СЛИЗОВОЇ ОБОЛОНКИ ШЛУНКУ У ХВОРИХ НАХРОНІЧНИЙ} HELICOBACTER PYLORI-AСОЦIЙОВAНИЙ ГАСТРИТ

\section{Вернигородський С.В., Сухань Д.С.}

В теперішній час інфекція Helicobacter pylori (H. pylori) визнана одним із найважливіших фракторів ризику гастроканцерогенезу. Відомо, що дана інфекція не викликає безпосередньо неопластичні зміни в слизовій оболонці шлунку, а відбувається це внаслідок ряду послідовних подій за рахунок тривалої персистенції збудника в організмі людини. Початковим етапом даного каскаду, безумовно, є запальна відповідь, яка обумовлена здатністю організму адаптуватися до сторонньої інфекції та є неминучим результатом взаємодії Н. pylori з клітинами шлункового епітелію. Цей пошкоджуючий прямий ефект посилюється 
продукцією вакуолізуючого цитотоксину й вивільненням продуктів цитотоксин-асоційованого гена СаgA, що на патоморфологічному рівні проявляється запальною інфрільтрацією слизової оболонки шлунку (СОШ) того чи іншого ступеня. Щодо зв'язку між ступенем обсіменіння (контамінації) та активності запалення СОШ у людей, інфрікованих штамом СаgА, на сьогодні існують різні, часто суперечливі думки, ось чому в даній роботі ми поставили за мету встановлення взаємозв'язку між характером запальної відповіді та наявності гену CagA у H. pylori-інфікованих хворих. Мета дослідження - встановлення взаємозв'язку між характером запальної відповіді та генетичнихми особливостями штаму Н. руІогі (наявності генотипу CagA). Нами було обстежено 365 пацієнтів, серед яких до контрольної групи увійшли 40 осіб (18 жіночої та 22 чоловічої

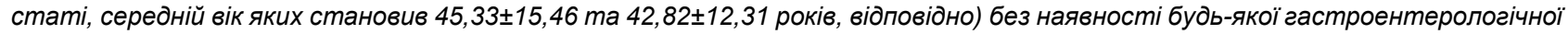
патології в анамнезі, хворих на хронічний неатрофрічний гастрит (188 осіб) та хронічний атрофрічний гастрит (137 осіб). Встановлений, тісний зв'язок між наявністю гену CagA, активністю та ступенем контамінації для хронічного неатрофрічного гастриту: для низького ступеня контамінації точний критерій Фішера становив $=0,002, p<0,05$, для помірного ступеня 0,012, p<0,05, для високого ступеня - 0,012, p<0,05. Відповідно, при хронічному атрофрічному гастриті: для низького ступеня контамінації точний критерій Фішера =0,011, p<0,05, для помірного ступеня - 0,003, p<0,05, для високого ступеня - 0,001, $p<0,05$. Зареєстрований також тісний зв'язок між ступенем контамінації та активністю хронічного гастриту (XГ): $y$ хворих з високим ступенем контамінації виявляли, як правило, 2-3 стадію активності ХГ. У нашому дослідженні запальна відповідь залежала від наявності, або відсутності у пацієнта штаму H. руlori, що містив генотип CagA, котрий, на нашу думку, займає ключову роль у запуску каскада запальних змін СОШ та прогресуванні хронічного гастриту.

Ключові слова: Helicobacter pylori, CagA, хронічний гастрит, морфологічні зміни.

\section{РОЛЬ СаgА ГЕНА В ВОЗНИКНОВЕНИИ ВОСПАЛИТЕЛЬНОГО ОТВЕТА СЛИЗИСТОЙ ОБОЛОЧКИ ЖЕЛУДКА У БОЛЬНЫХ ХРОНИЧЕСКИМ HЕLICOBAСTER PYLORI-AССОЦИИРОВАННЫМ ГАСТРИТОМ \\ Вернигородский С.В., Сухань Д.С.}

В настоящее время инфекция Helicobacter pylori (H. pylori) признана одним из важнейших фракторов риска гастроканцерогенеза. Известно, что данная инфекция не вызывает непосредственно неопластические изменения в слизистой оболочке желудка, а происходит это вследствие ряда последовательных событий за счет длительной персистенции возбудителя в организме человека. Начальным этапом данного каскада, безусловно, является воспалительный ответ, который обусловлен способностью организма адаптироваться к посторонней инфекции и является неизбежным результатом взаимодействия H. pylori с клетками желудочного эпителия. Этот повреждающий прямой эффрект усиливается продукцией вакуолизирующего цитотоксина и высвобождением продуктов цитотоксин-ассоциированного гена СagA, что на патоморфологическом уровне проявляется воспалительной инфрильтрацией слизистой оболочки желудка (СОЖ) той или иной степени. По связи между степенью обсеменения (контаминации) и активности воспаления СОЖ у людей, инфицированных штаммом СаgA, на сегодняшний день существуют различные, часто противоречивые мнения, вот почему в данной работе мы поставили цель установления взаимосвязи между характером воспалительного ответа и наличием гена CagA y H. Pyloriинфицированных больных. Цель исследования - установление взаимосвязи между характером воспалительного ответа и генетическими особенностяими штамма Н. pylori (наличия генотипа CagA). Нами было обследовано 365 пациентов, среди которых в контрольную группу вошли 40 человек (18 женского и 22 мужского пола, средний возраст которых составлял

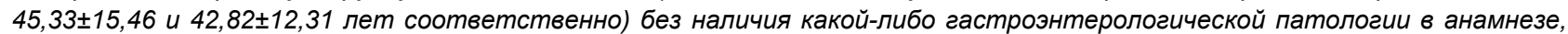
больных хроническим неатрофрическим гастритом (188 человек) и хроническим атрофрическим гастритом (137 человек). Установлена тесная связь между наличием гена СagA, активностью и степенью контаминации для хронического неатрофического гастрита: для низкой степени контаминации точный критерий Фишера составлял 0,002, р<0,05, для умеренной степени - 0,012, p<0,05, для высокой степени - 0,012, p<0,05. Соответственно, при хроническом атрофическом гастрите: для низкой степени обсеменения точный критерий Фишера был равен 0,011, p<0,05, для умеренной степени $0,003, p<0,05$, для высокой степени - 0,001, p<0,05. Зарегистрирована также тесная связь между степенью контаминации и активностью хронического гастрита (ХГ): так у больных с высокой степенью контаминации определяли, как правило, 23 стадию активности ХГ. В нашем исследовании воспалительный ответ зависел от наличия или отсутствия у пациента штамма H. pylori, содержащий генотип CagA, который, по нашему мнению, занимает ключевую роль в запуске каскада воспалительных изменений СОЖ и прогрессировании хронического гастрита.

Ключевые слова: Helicobacter pylori, CagA, хронический гастрит, морфологические изменения. 